\title{
Infectivity of a Scottish isolate of Piscirickettsia salmonis for Atlantic salmon Salmo salar and immune response of salmon to this agent
}

\author{
T. Harry Birkbeck ${ }^{1, *}$, Shona Rennie ${ }^{1}$, Douglas Hunter ${ }^{2}$, L. Anthony Laidler ${ }^{2}$, \\ Simon Wadsworth ${ }^{2,3}$
}
${ }^{1}$ Institute of Biomedical and Life Sciences, Division of Infection and Immunity, Joseph Black Building,University of Glasgow, Glasgow G12 8QQ, Scotland, UK
${ }^{2}$ Marine Harvest Scotland, Lochailort, Inverness-shire PH38 4LZ, Scotland, UK

${ }^{3}$ Present address: EWOS Innovation, 4335 Dirdal, Norway

\begin{abstract}
A Scottish isolate of Piscirickettsia salmonis (SCO-95A), previously shown by intraperitoneal injection to have a lethal dose $\left(\mathrm{LD}_{50}\right)$ of $<2 \times 10^{3}$ infectious rickettsial units, was tested for virulence by bath challenge, surface application to the skin, or dorsal median sinus injection. Atlantic salmon Salmo salar post-smolts were used in all experiments, and exposure to $1 \times 10^{5}$ tissue culture infective doses (TCID) of $P$. salmonis $\mathrm{ml}^{-1}$ for $1 \mathrm{~h}$ in a bath challenge resulted in only 1 mortality, $18 \mathrm{~d}$ later, in 10 exposed fish. Application of $2.5 \times 10^{6} \mathrm{TCID}$ of $P$. salmonis SCO-95A to paper discs on the skin failed to induce any mortalities within $42 \mathrm{~d}$. Intraperitoneally, fish were administered vaccines containing $10^{9}$ heat-inactivated $\left(100^{\circ} \mathrm{C}, 30 \mathrm{~min}\right)$ or $10^{9}$ formalin-inactivated $P$. salmonis SCO-95A in adjuvant, with a control group receiving phosphate-buffered saline (PBS) in adjuvant. After an induction period of over 6 mo fish were challenged by injection of $P$. salmonis into the dorsal median sinus. Mortalities in the control group reached $81.8 \%$ and the heat-inactivated and formalin-inactivated vaccines gave significant protection from $P$. salmonis, with relative percentage survivals of 70.7 and $49.6 \%$, respectively. The nature of the protective antigen is unknown, but could be lipopolysaccharide or a heat-stable outer membrane protein. Fish that survived a dorsal median sinus challenge of $P$. salmonis or were cohabitants showed a strong immune response to P. salmonis.
\end{abstract}

KEY WORDS: Piscirickettsia salmonis - Piscirickettiosis · Salmonid rickettsial septicaemia · SRS · Immune response $\cdot$ Vaccine

\section{INTRODUCTION}

Piscirickettsiosis, formerly termed salmonid rickettsial septicaemia (SRS), was described as a new syndrome causing heavy losses of coho salmon in Chile in 1989 (Fryer et al. 1990, Branson \& Diaz-Munos 1991, Cvitanich et al. 1991) and growth in tissue culture cells revealed the causative agent to be a rickettsia-like organism (Fryer et al. 1990). Analysis of the 16S rDNA sequence defined the organism as a member of the $\gamma$ proteobacteria rather than the $\alpha$ proteobacteria that contains the Rickettsia (Fryer et al. 1992), and the organism was placed in a new genus as Piscirickettsia salmonis (Fryer at al. 1992). Since the first outbreaks of SRS in Chile it has been recognised on the Pacific and Atlantic coasts of Canada (Brocklebank et al. 1993, Jones et al. 1998), Norway (Olsen et al. 1993), Ireland (Rodger \& Drinan 1993) and Scotland (Grant et al. 1996, Birrell et al. 2003, Reid et al. 2004). Losses in Chile were reported to exceed 10 million fish in 1995 (Smith et al. 1997); in the northern hemisphere, losses have been very low by comparison, possibly reflecting the greater sensitivity of coho salmon Oncorhynchus kisutch to P. salmonis (Mauel \& Miller 2002).

Comparison of $16 \mathrm{~S}$ rDNA and the internal transcribed spacer (ITS) between the 16S and 23S rDNA 
showed that isolates of Piscirickettsia salmonis from Chile (LF-89 ${ }^{\mathrm{T}}, \mathrm{C} 1-95$ and SLGO-94), Norway (NOR92) and Canada (ATL-4-91) formed a homogeneous group with 1 outlier, the Chilean isolate EM-90 (Mauel et al. 1999). However, a more recent study by Reid et al. (2004) that included isolates from Scotland and Ireland showed much greater variation than previously recognised, with 2 Irish strains related to EM-90 and a further 2 Irish strains forming a new, distinct group more distant from all other recognised isolates. All 8 Scottish isolates obtained over a $7 \mathrm{yr}$ period were closely related and similar to the NOR-92 and ATL-491 isolates from Atlantic salmon (Reid et al. 2004). The incidence of SRS is increasing in Norway and Scotland, with 17 and 7 outbreaks of disease, respectively, recorded in 2002 (Olsen 2003, Reid et al. 2004).

Several studies have reported the effect of Chilean strains of Piscirickettsia salmonis, mainly LF-89 ${ }^{\mathrm{T}}$, on coho salmon, Atlantic salmon Salmo salar and rainbow trout Oncorhynchus mykiss (Smith et al. 1996, Almendras et al. 1997, House et al. 1999, Kuzyk et al. 2001), and one study included the effect of Strain NOR-92 on coho salmon (House et al. 1999). Herein we report on the infectivity of a Scottish isolate of P. salmonis administered to Atlantic salmon by various routes aimed at developing a challenge model to test the efficacy of experimental vaccines against SRS. We also show that vaccines prepared from inactivated $P$. salmonis give significant protection from $P$. salmonis challenge and that exposure of fish to $P$. salmonis induces a strong immune response to this organism.

\section{MATERIALS AND METHODS}

Bacteria. Piscirickettsia salmonis was isolated from Atlantic salmon Salmo salar during an outbreak of SRS in Scotland in 1995 (Grant et al. 1996) and subsequently identified as $P$. salmonis SCO-95A from its $16 \mathrm{~S}$ rDNA sequence and its reaction with a latex agglutination identification kit (Latex Agglutination Detection System Rickettsia, Microtek, Canada). Although homogenates of tissues from naturally or experimentally infected fish did not react positively in the latex agglutination test, homogenates of infected tissue cultures reacted with equal intensity to similar concentrations of LF-89 ${ }^{\mathrm{T}}$ from tissue cultures. Samples of kidney were removed aseptically from moribund naturally infected fish, homogenised and added to monolayer cultures of CHSE-214 (Chinook salmon embryo) cells in Eagle's minimal essential medium (MEM) containing 10\% foetal calf serum and $4 \mathrm{mM}$ glutamine (Invitrogen, UK). The SCO-95A strain was maintained in culture in CHSE-214 cells with subculture at 2 to $3 \mathrm{wk}$ intervals, and bacteria used in the experiments were at Passage
Nos. 50 to 60 in CHSE cells. Samples were also stored in liquid nitrogen in foetal calf serum containing $10 \%$ dimethyl sulphoxide.

Quantification of Piscirickettsia salmonis. The concentration of infectious piscirickettsial units or TCID of $P$. salmonis in cell cultures was determined by a form of plaque assay (Cvitanich et al. 1991) in which serial dilutions (up to $10^{-8}$ ) of homogenates of tissue-culture cells in Eagle's MEM were added to duplicate wells of monolayer cultures of CHSE-214 cells in Costar 24-well tissue-culture plates. After culture for $10 \mathrm{~d}$ at $18^{\circ} \mathrm{C}$, the medium was removed, cells Giemsa-stained and plaques resulting from $P$. salmonis replication were counted. Each plaque was considered to represent 1 TCID of $P$. salmonis in the original culture fluid and was considered approximately equivalent to 1 $\mathrm{TCID}_{50}$ (Smith et al. 1997).

Infectivity of Piscirickettsia salmonis by bath challenge. Birkbeck et al. (2004) showed that $P$. salmonis can be cultured in Sf21 insect cells with a yield approximately 60 to 100 times greater than that obtained in CHSE-214 cells and that the virulence for Atlantic salmon was unchanged. P. salmonis was cultured in four $175 \mathrm{~cm}^{2}$ flasks containing confluent monolayers of Sf 21 cells in $100 \mathrm{ml} \mathrm{TC100} \mathrm{medium}+10 \%$ foetal calf serum (Invitrogen). Complete disintegration of the cells had occurred within $12 \mathrm{~d}$ and the $400 \mathrm{ml}$ culture fluid (subsequently shown to contain $1 \times 10^{7}$ TCID of $P$. salmonis) was added to a tank containing ten $100 \mathrm{~g}$ Atlantic salmon post-smolts lightly anaesthetised with benzocaine in $40 \mathrm{l}$ seawater (final concentration of $P$. salmonis $=10^{5} \mathrm{TCID} \mathrm{ml}^{-1}$ ) at $14^{\circ} \mathrm{C}$. After $1 \mathrm{~h}$ the fish were transferred to a $1.5 \times 1.5 \mathrm{~m}$ tank at $14^{\circ} \mathrm{C}$ with running seawater of $35 \mathrm{~cm}$ depth and with a flow rate of 10 to $15 \mathrm{lh}^{-1}$.

Infectivity of Piscirickettsia salmonis by surface application. The method of Smith et al. (1999) was used. Suspensions of $P$. salmonis cultured in CHSE-214 cells and concentrated by centrifugation to contain $5 \times$ $10^{8} \mathrm{TCID} \mathrm{ml}^{-1}$ (Birkbeck et al. 2004) were applied (5 $\mathrm{\mu l}$ containing $2.5 \times 10^{6}, 2.5 \times 10^{4}$ or $2.5 \times 10^{2}$ TCID) to sterile Whatman filter-paper discs of $6 \mathrm{~mm}$ diameter. Eagle's MEM was used as a control fluid. A small area of the flank of a $100 \mathrm{~g}$ Atlantic salmon post-smolt, anaesthetised with $20 \mathrm{ppm}$ benzocaine was wiped with a tissue and the disc applied face down to the flank of the fish for $1 \mathrm{~min}$. Each group of 5 fish was marked with a pan-jet and fish were transferred to a $1.5 \times 1.5 \mathrm{~m}$ tank with running seawater of $35 \mathrm{~cm}$ depth and with a flow rate of 10 to $15 \mathrm{l} \mathrm{h}^{-1}$ at $14^{\circ} \mathrm{C}$ for the duration of the experiment.

Infectivity of Piscirickettsia salmonis by injection into dorsal median sinus. Groups of 5 Atlantic salmon post-smolts (250 to $300 \mathrm{~g}$ ) were lightly anaesthetised with benzocaine and marked by a pan-jet; $0.1 \mathrm{ml}$ 
CHSE-214-cultured P. salmonis suspension in Eagle's MEM $\left(3 \times 10^{5}, 3 \times 10^{4}\right.$ and $3 \times 10^{3}$ TCID per injection dose) was injected into the dorsal median sinus close to the dorsal fin. Fish were transferred to a $1.5 \times 1.5 \mathrm{~m}$ tank with running seawater of $35 \mathrm{~cm}$ depth and with a flow rate of 10 to $15 \mathrm{l} \mathrm{h}^{-1}$ at $14^{\circ} \mathrm{C}$ for the duration of the experiment.

Preparation of Piscirickettsia salmonis bacterin vaccines. P. salmonis cultured in Sf21 cells was collected by centrifugation at $10000 \times g$ for $10 \mathrm{~min}$ at $4^{\circ} \mathrm{C}$, washed twice in phosphate-buffered saline (PBS, $8.0 \mathrm{~g}$ $\mathrm{NaCl}_{1} 0.2 \mathrm{~g} \mathrm{KH}_{2} \mathrm{PO}_{4}, 2.8 \mathrm{~g} \mathrm{Na}_{2} \mathrm{HPO}_{4} .12 \mathrm{H}_{2} \mathrm{O}, 0.2 \mathrm{~g} \mathrm{KCl}$ ) and resuspended to $\mathrm{A} 600 \mathrm{~nm}=1.0$. This suspension was later found by titration to contain $5 \times 10^{8}$ TCID P. salmonis $\mathrm{ml}^{-1}$. Heat-inactivated bacterin was prepared by heating $90 \mathrm{ml}$ suspension at $100^{\circ} \mathrm{C}$ for $30 \mathrm{~min}$. Formalin-inactivated bacterin was prepared by treatment of $90 \mathrm{ml}$ of the above suspension of $P$. salmonis with formalin (final concentration of formaldehyde = $1 \% \mathrm{v} / \mathrm{v}$ ) for $24 \mathrm{~h}$ at $4^{\circ} \mathrm{C}$. Cells were collected by centrifugation, washed twice with PBS and resuspended in $0.1 \%$ formaldehyde in PBS. To prepare injection mixtures, cells were collected by centrifugation at $10000 \times g$ for 10 min at $4^{\circ} \mathrm{C}$, washed once in PBS, adjusted to a concentration of $1.5 \times 10^{10} \mathrm{ml}^{-1}$ in PBS and emulsified with 2 volumes of Montanide 711 adjuvant to provide $10^{9}$ inactivated cells per $0.2 \mathrm{ml}$ vaccine dose.

We anaesthetised 3 groups of 60 Atlantic salmon post-smolts $(\sim 100 \mathrm{~g}$ weight) with benzocaine (final concentration $20 \mathrm{ppm}$ ), and $0.2 \mathrm{ml}$ of PBS emulsified in adjuvant, heat-inactivated cells + adjuvant or formalininactivated cells + adjuvant was injected intraperitoneally. Fish were maintained in a separate tank for each group in ambient seawater (mean temperature approximately $10^{\circ} \mathrm{C}$ ) for $194 \mathrm{~d}$ before challenge.

Due to tank-space limitations it was not possible to hold all fish at elevated temperature during the challenge with Piscirickettsia salmonis, and each group was divided into 2 tanks, one held in seawater at ambient temperature $\left(7.5^{\circ} \mathrm{C}\right)$ and the other transferred from seawater to freshwater and gradually acclimatised to $16^{\circ} \mathrm{C}$. P. salmonis was grown in CHSE cells (Titre $2 \times 10^{5} \mathrm{TCID} \mathrm{ml}^{-1}$ ) and $0.1 \mathrm{ml}$ (i.e. $2 \times 10^{4} \mathrm{TCID}$ fish $^{-1}$ ) was injected into the dorsal median sinus of anaesthetised fish of 500 to $700 \mathrm{~g}$ weight. Fish were maintained at 7.5 to $8.5^{\circ} \mathrm{C}$ in seawater or $16^{\circ} \mathrm{C}$ in freshwater for $54 \mathrm{~d}$.

Confirmation of the presence of Piscirickettsia salmonis in moribund or dead fish. Fish were inspected at least 3 times daily and dead or moribund fish were removed from tanks and frozen at $-80^{\circ} \mathrm{C}$ to await bacteriological examination. In small batches, fish were thawed, sections of kidney removed aseptically, homogenised and serial dilutions in Eagle's MEM applied to monolayer cultures of CHSE-214 cells.
Monolayers were examined after 10 to $15 \mathrm{~d}$ for cytopathic effects and visible piscirickettsia within inclusions in the cells.

ELISA of anti-Piscirickettsia salmonis antibody titres in fish. As many of the serum samples were from fish that had been immunised with $P$. salmonis cultured in Sf 21 cells, a single preparation of $P$. salmonis grown in CHSE-214 cells was used as the antigen preparation and stored frozen in small quantities at $-20^{\circ} \mathrm{C}$. Each well of a Dynatech Immulon 1 96-well plate was treated with $1000 \mu \mathrm{l} P$. salmonis antigen suspension diluted 1/20 in $0.05 \mathrm{M}$ carbonate buffer, pH 9.6 (coating buffer) for $3 \mathrm{~h}$ at $4^{\circ} \mathrm{C}$. The antigen solution was removed and replaced with $100 \mu \mathrm{ll} 10 \%$ dried milk solution overnight at $4^{\circ} \mathrm{C}$. Doubling dilutions of each salmon serum $(100 \mu \mathrm{l})$, beginning at $1 / 200$, were added to each row and the plate was incubated for $2 \mathrm{~h}$ at $37^{\circ} \mathrm{C}$. The plate was washed twice with PBS-T (PBS + $0.05 \%$ Tween 20) in an automated plate-washer (Luminar Technology Swatwash) and blotted dry. Rabbit antisalmon immunoglobulin antiserum $(100 \mu \mathrm{l}$ diluted 1/3200) was added to each well and the plate incubated for $2 \mathrm{~h}$ at $37^{\circ} \mathrm{C}$. After removal of the well contents and washing twice with PBS-T, $100 \mu \mathrm{l}$ horseradish peroxidase-labelled donkey anti-rabbit immunoglobulin (Scottish Antibody Production Unit, diluted $1 / 1000$ in PBS-T) was added followed by incubation for $2 \mathrm{~h}$ at $37^{\circ} \mathrm{C}$. After twice washing with PBS-T, $100 \mu \mathrm{l}$ substrate solution (34 mg o-phenylenediamine dihydrochloride dissolved in $0.05 \mathrm{M}$ citric acid/0.1 M $\mathrm{Na}_{2} \mathrm{HPO}_{4}$, pH 5.0 buffer, with $20 \mu$ l hydrogen peroxide solution added $100 \mathrm{ml}^{-1}$ immediately prior to use) was applied to each well. After colour development in the dark for 30 min the reaction was stopped by addition of $50 \mu \mathrm{l} 12.5 \%$ sulphuric acid per well and absorbance read at $492 \mathrm{~nm}$ in an ELISA plate reader (Dynatech). The end-point in ELISA titrations was determined graphically as the reciprocal of the dilution yielding A492 $\mathrm{nm}=0.25$. All chemicals were obtained from Sigma-Aldrich.

Serum samples for ELISA. Blood was taken aseptically from 10 fish at a sea site with no history of Piscirickettsia salmonis (unexposed); from 10 fish from a sea site at which SRS was confirmed, but from an adjacent pen to that containing infected fish (exposed); from 5 normal fish from an unrelated trial at the Lochailort Trials Unit (normal); from 10 fish which survived dorsal median sinus injection of $3 \times 10^{3}$ to $3 \times$ $10^{5}$ TCID of $P$. salmonis (challenged); and from 5 cohabitants from the same trial (cohabitants).

Statistical analysis. Statistical analyses were performed with Minitab Version 13. A $\chi^{2}$ test was used to compare differences in survival in the vaccine trial, and the non-parametric Kruskal-Wallis $H$-test was used to compare differences in median antibody titres 
between groups. As it has been reported that antibody titres are usually log-normally distributed rather than normally distributed (Wardlaw 1999), ELISA data was analysed both before and after logarithmic transformation but the same results were obtained in both cases. A significant difference was defined as a p-value of $<0.05$.

\section{RESULTS}

\section{Infectivity of Piscirickettsia salmonis by bath challenge}

Birkbeck et al. (2004) showed that intraperitoneal injection of Piscirickettsia salmonis SCO-95A is virulent for Atlantic salmon, with an $\mathrm{LD}_{50}$ of $<2 \times 10^{3}$ TCID, but that only 1 of 20 cohabitant fish held in the same tank succumbed to SRS. Therefore, we exposed fish to $1 \times 10^{5}$ TCID ml ${ }^{-1}$ P. salmonis for $1 \mathrm{~h}$ in a bath challenge. Of 10 exposed fish, only 1 died (Day 18) of SRS during the experiment.

\section{Infectivity of Piscirickettsia salmonis by surface application}

Application of Piscirickettsia salmonis to the flank of Atlantic salmon via a filter paper (Smith et al. 1999) failed to induce any mortalities within $42 \mathrm{~d}$, even at the highest dose tested $\left(2.5 \times 10^{6} \mathrm{TCID} \mathrm{fish}^{-1}\right)$.

\section{Infectivity of Piscirickettsia salmonis by injection into dorsal median sinus}

Because of the difficulty in inducing SRS by cohabitation, bath challenge, or surface application, the dorsal median sinus was chosen as a route of injection of
Piscirickettsia salmonis to challenge fish in vaccine studies. This was to avoid introducing organisms to the site of administration of the adjuvanted vaccine in the peritoneal cavity. Mortalities induced were 2/5, 3/5 and $0 / 5$ for groups administered $3 \times 10^{5}, 3 \times 10^{4}$ and $3 \times 10^{3}$ TCID, respectively. The experiment was terminated on Day 46 after challenge, when serum was taken from surviving fish including all 5 cohabitant fish to assess their immune response to $P$. salmonis.

\section{Vaccination of Atlantic salmon with Piscirickettsia salmonis bacterins}

In this experiment, 2 vaccines were prepared from the same stock of Piscirickettsia salmonis by heat inactivation at $100^{\circ} \mathrm{C}$ for $30 \mathrm{~min}$ or by formaldehyde treatment to investigate the contribution of lipopolysaccharide (LPS), which is heat-stable, and outer membrane proteins, which are generally heat-labile. The vaccines were emulsified in adjuvant, and a control group was administered PBS in adjuvant. After an induction period of $194 \mathrm{~d}$ at a mean temperature of $10^{\circ} \mathrm{C}$, fish were challenged by injection of $2 \times 10^{4} \mathrm{TCID}$ of $P$. salmonis into the dorsal median sinus and maintained either in ambient seawater $\left(7.5^{\circ} \mathrm{C}\right)$ or in freshwater at $16^{\circ} \mathrm{C}_{i} 5$ fish that died within $2 \mathrm{~d}$ of injection with $P$. salmonis were discounted. None of the fish held at $7.5^{\circ} \mathrm{C}$ died or showed any sign of SRS over $54 \mathrm{~d}$. For fish maintained in fresh water, mortalities confirmed to be associated with SRS occurred from Day 26 onwards. On Day 34, 23 moribund fish were culled on welfare grounds, and P. salmonis infection was confirmed in these fish. The experiment was terminated on Day 54, when mortality had reached 24.0 and $47.6 \%$ in the heat-inactivated and formolised vaccine groups, respectively (Fig. 1). The mortality in the control group administered PBS + aduvjant was 81.8\%;

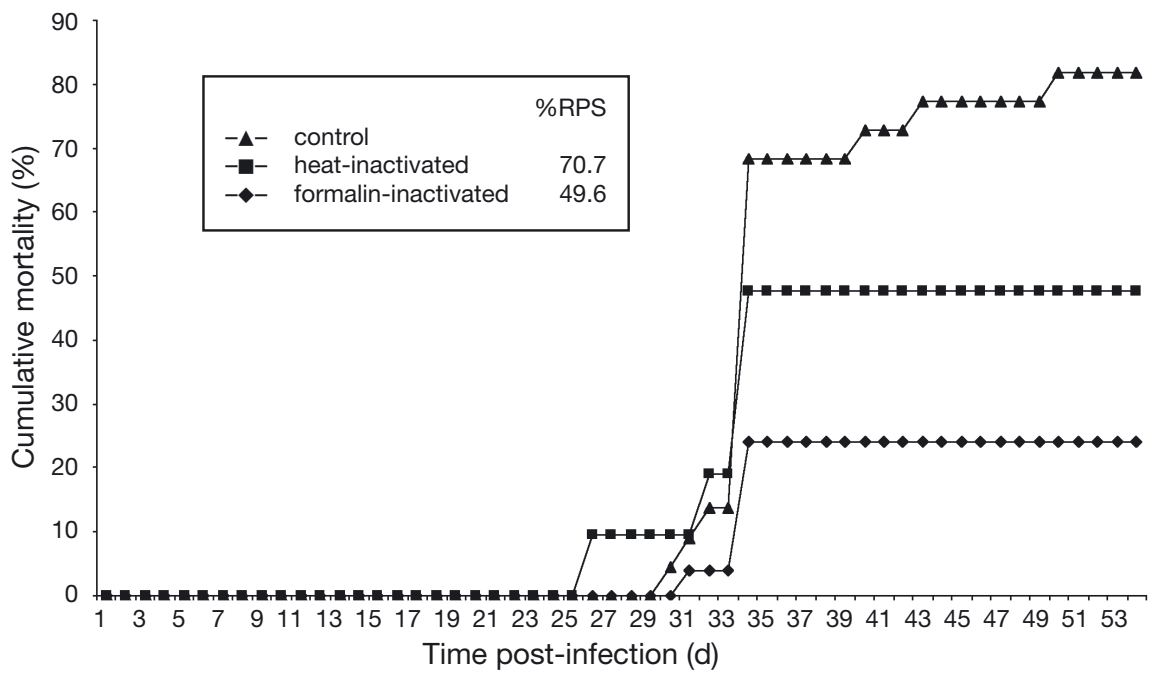

Fig. 1. Salmo salar infected with Piscirickettsia salmonis. Comparison of 2 bacterin vaccines for protection of Atlantic salmon post-smolts from salmonid rickettsial septicaemia. Fish were challenged by injection of $P$. salmonis SCO-95A (10 $0^{4.3}$ infectious rickettsial units) into dorsal median sinus $194 \mathrm{~d}$ after vaccination and held at $16^{\circ} \mathrm{C}$ in fresh water. All samples were emulsified in Montanide 711 adjuvant and bacterins contained equivalent of $10^{9}$ infectious rickettsial units. When experiment was terminated, mortalities were PBS control: 18 of 22 fish; heat-inactivated bacterin: $6 / 25$; formalin-inactivated bacterin: 10/21. RPS: relative percentage survical 


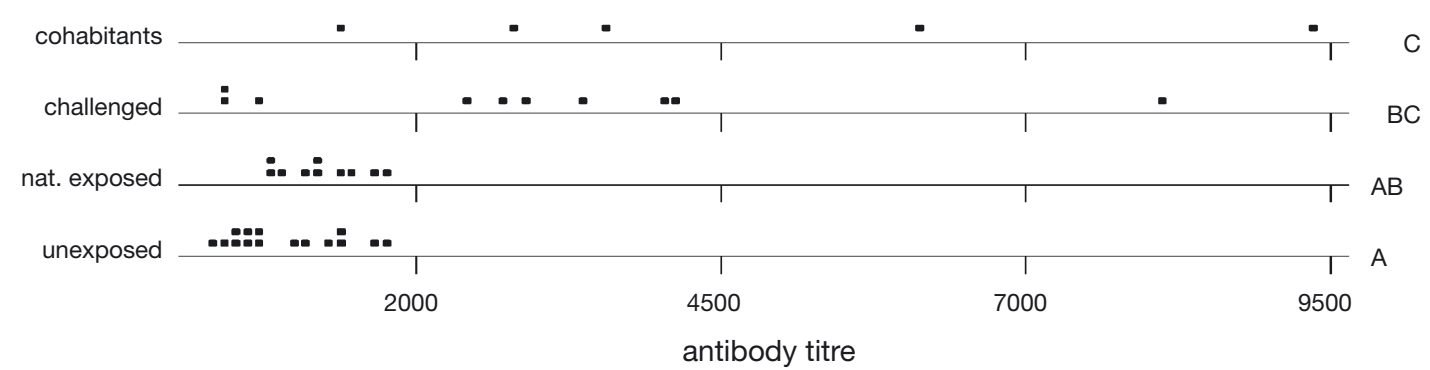

Fig. 2. Salmo salar infected with Piscirickettsia salmonis. Dot-plots of anti-P. salmonis antibody titres in sera of control Atlantic salmon or those exposed to P. salmonis. Groups were unexposed: 10 fish from site with no history of salmonid rickettsial septicaemia (SRS) and 5 fish from an unrelated experiment; naturally exposed: 10 fish from neighbouring pen at site experiencing SRS; challenged: 10 fish surviving dorsal median sinus injection of $P$. salmonis 46 d previously; cohabitants: 5 cohabitant fish held in same tank as 'challenged' fish. Significant differences $(p<0.05)$ between groups are indicated by different letters; groups with same letter were not significantly different

the relative percentage survival (RPS) in the group that received heat-inactivated vaccine was $70.7 \%\left(\chi^{2} ; \mathrm{p}<\right.$ $0.001)$; the RPS in the formolised vaccine group was $49.6 \%\left(\chi^{2} ; \mathrm{p}<0.05\right)$.

\section{Immune response of fish to Piscirickettsia salmonis}

All 15 sera from fish at 2 sites not exposed to SRS had ELISA titres of $<1800$, as did all 10 fish from a site at which SRS was confirmed in neighbouring pens. Of the 10 fish that survived dorsal median sinus challenge with Piscirickettsia salmonis, 7 had ELISA titres $>2000$, as did 4/5 cohabitants in the same experiment (Fig. 2). The median ELISA titre of fish surviving SRS-challenge (2772) was significantly greater $(p=0.027)$ than that of unexposed fish (943) but not significantly greater than that of exposed fish. For cohabitants, the median titre (3550) was significantly greater than that of unexposed fish (median $=943, \mathrm{p}=0.005$ ) and SRSexposed fish $($ median $=1192, \mathrm{p}=0.010)$.

\section{DISCUSSION}

A reliable challenge model for piscirickettsiosis is essential for the development of effective vaccines against Piscirickettsia salmonis. Cohabitation provides the most satisfactory challenge method for vaccine studies, as this mimics natural exposure most closely and requires the organism to overcome external as well as internal host defences (Nordmo 1997). Although injection challenges are regarded as more reliable, if adjuvanted vaccines are delivered by intraperitoneal injection (i.p.) then challenge by this route is not ideal, as adjuvant alone can give some long-term protection (Olivier et al. 1985). Intraperitoneal injection of Type Strain LF-89 ${ }^{\mathrm{T}}$ is highly virulent for coho salmon, with an $\mathrm{LD}_{50}$ of $10^{1.5} \mathrm{TCID}_{50}$, but it is less virulent for rainbow trout, for which an $\mathrm{LD}_{50}$ of
$10^{4.7} \mathrm{TCID}_{50}$ was found by Smith et al. (1997). House et al. (1999) recorded an $\mathrm{LD}_{50}$ of $<10^{3} \mathrm{TCID}_{50}$ for $\mathrm{LF}-89^{\mathrm{T}}$ injected intraperitoneally into coho salmon and the median times to death of their groups of fish injected with $10^{5}, 10^{4}$ and $10^{3}$ TCID $_{50}$ were almost identical to those found in this study $(16,26$ and $40 \mathrm{~d}$ compared with 17,25 and $40 \mathrm{~d}$, respectively). Therefore, the virulence of Strain SCO-95A by intraperitoneal injection in Atlantic salmon appears to be comparable to that of LF-89 ${ }^{\mathrm{T}}$ in coho salmon.

The only study to compare the virulence of strains of Piscirickettsia salmonis from different geographic locations is that of House et al. (1999), who found Canadian and Norwegian isolates from Atlantic salmon (ATL-491 and NOR-92) to be less virulent for coho salmon (with $\mathrm{LD}_{50} \mathrm{~S}$ of $10^{3.4}$ and $10^{4.6} \mathrm{TCID}_{50}$, respectively) than Coho Salmon Strain LF89 ${ }^{\mathrm{T}}\left(\mathrm{LD}_{50}<10^{3} \mathrm{TCID}_{50}\right)$.

Our lack of success in generating SRS by bath immersion is similar to the finding of Smith et al. (1997) for rainbow trout. Immersion challenge of rainbow trout for $3 \mathrm{~min}$ in a suspension of Piscirickettsia salmonis at $5.7 \times 10^{4} \mathrm{TCID}_{50} \mathrm{ml}^{-1}$ (approximately $1 \mathrm{LD}_{50} \mathrm{ml}^{-1}$ by i.p. injection) did not cause clinical disease or mortality, although piscirickettsia were detected in tissues from 45 min post-exposure onward, throughout the trial (Smith et al. 1997). Both the challenge dose and time of exposure employed here were greater than those used by Smith et al. (1997), with fish exposed to ca. $500 \mathrm{LD}_{50} \mathrm{ml}^{-1}$ for $1 \mathrm{~h}$ still able to generate only 1 mortality in 10 fish.

As no invertebrate vector has been found for piscirickettsia (Mauel \& Miller 2002, Fryer \& Hedrick 2003, Birkbeck et al. 2004), it is considered to be transmitted via water. Cvitanich et al. (1991) showed that transmission of SRS was possible from injected fish to cohabitants, with the latter dying 31 and $37 \mathrm{~d}$ after exposure to injected fish in seawater and freshwater aquaria, respectively, at $15^{\circ} \mathrm{C}$. Only 1 study to date has reported high transmissibility of Piscirickettsia salmonis by cohabitation. Almendras et al. (1997) reported a 
Chilean isolate of $P$. salmonis from Atlantic salmon to be highly virulent for Atlantic salmon by injection and contact or non-contact cohabitation. Intraperitoneal injection of only 14.8 TCID $_{50}$ of Strain NCR1010 led to $57 \%$ mortalities between 17 and $23 \mathrm{~d}$ post-injection, and 59 and $50 \%$, of contact and non-contact cohabitants, respectively, died between 17 and $28 \mathrm{~d}$ at $11^{\circ} \mathrm{C}$. Since many of these fish were also found to be infected with Aeromonas salmonicida, the high mortalities resulting from such a low infectious dose may have been due to a co-operative interaction of these bacteria on the immune system.

Smith et al. (1999) concluded that the skin and gills represent the natural route of entry of Piscirickettsia salmonis into salmonids, and induced $52 \%$ mortalities in rainbow trout following application of $10^{4.2} \mathrm{TCID}_{50} P$. salmonis via a skin patch for $1 \mathrm{~min}$. In the present study, no mortalities were induced by this method in Atlantic salmon when approximately $1000 \mathrm{LD}_{50}$ SCO-95A were applied to filter-paper discs. Therefore, although the Scottish Strain SCO-95A was virulent by injection (Birkbeck et al. 2004), it was very poorly transmissible by cohabitation, bath challenge or surface application, and dorsal median sinus injection was chosen for a subsequent vaccine challenge.

Good protection against Piscirickettsia salmonis challenge was obtained in groups of fish vaccinated with either the heat-inactivated or formalin-inactivated bacterins and challenged at $16^{\circ} \mathrm{C}$. Temperature is an important factor in the development of SRS, and no deaths occurred in fish held in ambient seawater at 7.5 to $8.5^{\circ} \mathrm{C}$ after injection of $P$. salmonis. Also, an outbreak of SRS at a farm site in Scotland was resolved naturally by falling water temperatures (A. Grant pers. comm.). The interval between vaccination and challenge exceeded 6 mo in this study, indicating that prolonged and significant immunity to SRS was induced. As greater protection was obtained with the heatinactivated bacterin (RPS $=70.7 \%$ ) than with formalinised bacterin (RPS $=49.6 \%$ ), it appears that the protective antigen(s) are heat-stable, and these would be present in both preparations. The dominant heat-stable immunogen of the Gram-negative bacterial cell envelope is lipopolysaccharide (LPS) and this is considered the protective antigen in vaccines against Vibrio anguillarum (Evelyn 1984) and Yersinia ruckeri (Stevenson 1997). Although LPS is a T-independent antigen (Janeway et al. 1999) the protection induced by the above vaccines can exceed 1 yr (Johnson et al. 1982). The vast majority of proteins would be denatured by heating at $100^{\circ} \mathrm{C}$ for $30 \mathrm{~min}$, but it is possible that a heat-stable protein could be the protective antigen, rather than LPS. Smith et al. $(1995,1997)$ tested $P$. salmonis bacterin vaccines in 2 field trials in Chile. Fish vaccinated $13 \mathrm{wk}$ prior to transfer to sea with
$10^{5.7} \mathrm{TCID}_{50}$-formalinised P. salmonis suffered approximately $3 \%$ mortality compared with approximately $15 \%$ loss in control fish that received PBS $\left(\chi^{2} ; \mathrm{p}<0.05\right)$. Interestingly, fish receiving $10^{6.1} \mathrm{TCID}_{50}$-formalinised P. salmonis in Freund's complete adjuvant suffered greater losses than the control group. In a second trial, fish vaccinated with $10^{5.5} \mathrm{TCID}_{50}$-formalinised $P$. salmonis without adjuvant $4 \mathrm{wk}$ prior to transfer to sea experienced significantly greater mortality $(40 \%)$ than the control group $(24 \%)$, indicating a possible immunosuppressive action of some component of $P$. salmonis. However, this was not supported by a laboratory trial using rainbow trout, in which similar bacterin vaccines gave significant protection (2 to $4 \%$ mortality versus $20 \%$ in a control group) from intraperitoneal injection of Strain LF89 (Smith et al. 1997). In a further bacterin vaccine trial, Kuzyk et al. (2001) obtained weak protection of coho salmon challenged with $P$. salmonis LF-89 ${ }^{\mathrm{T}}$ after a $3 \mathrm{wk}$ induction period at $10^{\circ} \mathrm{C}$. Vaccines containing approximately $10^{5}$ and $10^{4} \mathrm{TCID}_{50}$ in adjuvant gave RPS values of 15 and 17.5, respectively, whereas a 1/20 dilution (approximately $10^{3.7} \mathrm{TCID}_{50}$ ) showed enhanced mortality (RPS $=-30 \%$ ). The recombinant $P$. salmonis OspA vaccine developed by Kuzyk et al. (2001) gave good protection, comparable to that of the bacterin vaccine described herein, and if OspA (a lipoprotein of approximately $17 \mathrm{kDa}$ ) is heat-stable when in the $P$. salmonis outer membrane, it cannot be ruled out as a possible protective antigen in this study.

The immunising dose applied in this study $\left(10^{9}\right.$ bacteria) was comparable with that used in commercially available fish vaccines but much greater than in the bacterin vaccines of Smith et al. (1995) and Kuzyk et al. (2001). The latter studies were limited by the relatively low yield of Piscirickettsia salmonis obtained in CHSE214 cells, but production of larger quantities of $P$. salmonis in insect cells (Birkbeck et al. 2004) permits a wider range of cell concentrations to be used in vaccines to establish vaccine efficacy.

A significant immune response was detected in 7 of 10 fish that survived challenge with Piscirickettsia salmonis and in 4 of 5 cohabitant fish sampled (Fig. 2), indicating that the cohabitants had experienced significant exposure to $P$. salmonis without displaying overt disease.

Using a radio-immunoassay, Smith et al. (1997) detected an immune response in rainbow trout and coho salmon that survived natural SRS infection in Chile, as well as in vaccinated and experimentally challenged coho salmon. Although details were not provided, the magnitude of the response appears similar to that detected in Atlantic salmon in the present study, using ELISA. In this study, no immune response was detected in fish from a site experiencing an outbreak of 
SRS in adjacent cages. However, Smith et al. (1995) noted that it is common to find severe piscirickettsiosis in some cages on a site, with fish in neighbouring cages apparently unaffected.

The specificity of the antibodies induced in the present study was not investigated in detail. Native Piscirickettsia salmonis SCO-95A was used as target antigen for the ELISA measurements, but similar results were found for most sera tested with heat-inactivated antigen (results not shown). For fish that responded to a $P$. salmonis recombinant OspA vaccine, Kuzyk et al. (2001) found no correlation between antibody titres to OspA and protection from P. salmonis infection. Thus, although fish have been shown to respond to many antigens of P. salmonis (Kuzyk et al. 1996, 2001), the dominant protective antigen remains to be identified so that effective vaccines can be developed.

Acknowledgements. We thank P. Smith, Aquaculture Vaccines Ltd, for the gift of Montanide adjuvant.

\section{LITERATURE CITED}

Almendras FE, Fuentealba IC, Jones SRM, Markham F, Spangler E (1997) Experimental infection and horizontal transmission of Piscirickettsia salmonis in freshwaterraised Atlantic salmon, Salmo salar L. J Fish Dis 20: 409-418

Birkbeck TH, Griffen AA, Reid HI, Laidler LA, Wadsworth S (2004) Growth of Piscirickettsia salmonis to high titer in insect cells. Infect Immun 72:3693-3694

Birrell J, Mitchell S, Bruno DW (2003) Piscirickettsia salmonis in farmed Atlantic salmon, Salmo salar in Scotland. Bull Euro Assoc Fish Pathol 23:213-217

Branson EJ, Diaz-Munos D (1991) Description of a new disease condition occurring in farmed coho salmon, Oncorhynchus kisutch (Walbaum) in South America. J Fish Dis 14:147-156

Brocklebank JR, Speare DJ, Armstrong RD, Evelyn, TP (1993) Septicaemia suspected to be caused by a rickettsia-like agent in farmed Atlantic salmon. Can Vet J 33:407-408

Cvitanich JD, Garate NO, Smith CE (1991) The isolation of a rickettsia-like organism causing disease and mortality in Chilean salmonids and its confirmation by Koch's postulates. J Fish Dis 14:121-145

Evelyn TPT (1984) Immunization against pathogenic vibrios. In: Kinkelin P (ed) Symposium on Fish Vaccination, Office International des Epizooties, Paris, p 121-150

Fryer JL, Hedrick RP (2003) Piscirickettsia salmonis: a gramnegative intracellular bacterial pathogen of fish. J Fish Dis 26:251-262

Fryer JL, Lannan CN, Garcès LH, Larenas JJ, Smith PA (1990) Isolation of a rickettsiales-like organism from diseased coho salmon Oncorhynchus kisutch in Chile. Fish Pathol 25:107-114

Fryer JL, Lannan CN, Giovannoni SJ, Wood ND (1992) Piscirickettsia salmonis gen. nov., sp. nov., the causative agent of an epizootic disease in salmonid fishes. Int J System Bacteriol 42:120-126

Grant AN, Brown AG, Cox DI, Birkbeck TH, Griffen AA (1996) Rickettsia-like organism in farmed salmon. Vet Record 138:423

Editorial responsibility: David Bruno, Aberdeen, Scotland, United Kingdom
House ML, Bartholemew JL, Winton JR, Fryer JL (1999) Relative virulence of three isolates of Piscirickettsia salmonis for coho salmon Oncorhynchus kisutch. Dis Aquat Org 35: 107-113

Janeway CA, Travers P, Walport M, Capra JD (1999) Immunobiology, 4th edn. Churchill Livingstone, Edinburgh

Johnson KA, Flynn JK, Amend DF (1982) Duration of immunity in salmonids vaccinated by direct immersion with Yersinia ruckeri and Vibrio anguillarum bacterins. J Fish Dis 5:207-213

Jones SRM, Markham RJF, Groman DB, Cusack RR (1998) Virulence and antigenic characteristics of a cultured Rickettsiales-like organism isolated from farmed Atlantic salmon Salmo salar in Eastern Canada. Dis Aquat Org 33: $25-31$

Kuzyk MA, Thornton JC, Kay WW (1996) Antigenic characterization of the salmonid pathogen Piscirickettsia salmonis. Infect Immun 64:5205-5210

Kuzyk MA, Burian J, Machander D, Dolhaine D, Cameron S, Thornton JC, Kay WW (2001) An efficacious recombinant subunit vaccine against the salmonid rickettsial pathogen Piscirickettsia salmonis. Vaccine 19:2337-2344

Mauel MJ, Miller DL (2002) Piscirickettsiosis and piscirickettsiosis-like infections in fish:a review. Vet Microbiol 87:279-289

Mauel MJ, Giovannoni SJ, Fryer JL (1999) Phylogenetic analysis of Piscirickettsia salmonis by 16S, internal transcribed spacer (ITS) and 23S ribosomal DNA sequencing. Dis Aquat Org 35:115-123

Nordmo R (1997) Strengths and weaknesses of different challenge methods. In: Dev Biol Stand 90:303-309

Olivier G, Evelyn TPT, Lallier R (1985) Immunity to Aeromonas salmonicida in coho salmon (Oncorhynchus kisutch) induced by modified Freund's complete adjuvant: its non-specific nature and the probable role of macrophages in the phenomenon. Dev Comp Immunol 9:419-432

Olsen AB (2003) Oppblomstring av piscirickettsiose I Norge høsten 2002. Fiskehelse 5:6-8

Olsen $A B$, Evensen $\varnothing$, Spielberg L, Melby HP, Håstein T (1993) Ny laksesykdom forårsaket av rickettsie. Nor Fiskeoppdr 12:40-41

Reid HI, Griffen AA, Birkbeck TH (2004) Isolates of Piscirickettsia salmonis from Scotland and Ireland show evidence of clonal diversity. Appl Environ Microbiol 70:4393-4397

Rodger HD, Drinan EM (1993) Observation of a rickettsia-like organism in Atlantic salmon, Salmo salar L., in Ireland. J Fish Dis 16:361-369

Smith PA, Lannan CN, Garces LH, Jarpa M, Larenas J, Caswell-Reno P, Whipple M, Fryer JL (1995) Piscirickettsiosis: a bacterin field trial in coho salmon (Oncorhynchus kisutch). Bull Eur Assoc Fish Pathol 15:137-141

Smith PA, Contreras JR, Garces LH, Larenas JJ, CaswellReno P, Fryer JL (1996) Experimental challenge of coho salmon (Oncorhynchus kisutch) and rainbow trout (Oncorhynchus mykiss) with Piscirickettsia salmonis. J Aquat Anim Health 8:130-134

Smith PA, Contreras JR, Larenas JJ, Aguillon JC, Garces LH, Perez B, Fryer JL (1997) Immunization with bacterial antigens: piscirickettsiosis. Dev Biol Stand 90:161-166

Smith PA, Pizarro P, Ojeda P, Contreras J, Oyaneydel S, Larenas J (1999) Routes of entry of Piscirickettsia salmonis in rainbow trout Oncorhynchus mykiss. Dis Aquat Org 37:165-172

Stevenson RMW (1997) Immunization with bacterial antigens: yersiniosis. Dev Biol Stand 90:117-124

Wardlaw AC (1999) Practical statistics for experimental biologists, 2nd edn. Wiley, London

Submitted: December 29, 2003; Accepted: April 5, 2004

Proofs received from author(s): July 9, 2004 